DOI: https://doi.org/10.24127/ajpm.v10i3.3701

\title{
LAPISAN PEMAHAMAN KONSEP MAHASISWA CALON GURU MATEMATIKA DALAM MENYELESAIKAN SOAL LOGARITMA
}

\author{
Imanuel Gery Donuata ${ }^{1}$, Fika Widya Pratama ${ }^{2}$ \\ ${ }^{1,2}$ Universitas Kristen Satya Wacana, Salatiga, Indonesia \\ *Corresponding author. \\ E-mail: $\quad \frac{202017054 @ \text { student.uksw.edu }}{\text { f) }}$
}

Received 29 April 2021; Received in revised form 08 September 2021; Accepted 25 September 2021

\begin{abstract}
Abstrak
Penelitian ini bertujuan untuk mendeskripsikan lapisan pemahaman konsep mahasiswa calon guru matematika dalam menyelesaikan soal logaritma. Teori yang digunakan dalam mendeskripsikan lapisan pemahaman konsep adalah teori Pirie \& Kieren yang terdiri dari delapan lapisan, antara lain primitive knowing, image making, image having, property noticing, formalizing, observing, structuring, inventising. Jenis penelitian ini adalah deskriptif kualitatif. Subjek pada penelitian ini dipilih menggunakan teknik purposive sampling, sehingga terpilih 3 mahasiswa aktif dengan IPK tertinggi pada angkatan 2018, 2019 dan 2020 program studi Pendidikan Matematika, FKIP, Universitas Kristen Satya Wacana, Salatiga. Instrumen penelitian ini adalah peneliti sendiri sebagai instrumen utama dan instrumen pendukung berupa soal tes dan pedoman wawancara. Metode tes berupa soal persamaan logaritma dan metode wawancara digunakan untuk memperoleh data penelitian. Teknik analisis data yang digunakan antara lain reduksi data, data dianalisis dengan teori Pirie-Kieren, penyajian data dan penarikan kesimpulan. Uji keabsahan data menggunakan triangulasi teknik. Hasil penelitian menunjukan bahwa subjek 1 dan subjek 2 telah mencapai lapisan kedelapan, yaitu inventising. Sedangkan subjek 3 mencapai lapisan ketujuh, yaitu structuring. Berdasarkan hasil penelitian, dapat disimpulkan bahwa mahasiswa calon guru matematika telah mencapai lapisan kedelapan, yaitu inventising.
\end{abstract}

Kata kunci: Lapisan pemahaman konsep; logaritma; mahasiswa calon guru matematika.

\begin{abstract}
This research aims to describe the layer of conceptual understanding of preservice mathematis teacher in solving logarithmic problems. The theory used in describing layers of conceptual understanding is PirieKieren's theory which consists of eight layers, including primitive knowing, image making, image having, property noticing, formalizing, observing, structuring, inventising. This type of research is descriptive qualitative. The subjects in this research were selected using purposive sampling technique, so that 3 active students with the highest GPA were selected in the 2018, 2019 and 2020 Mathematics Education study programs, FKIP, Satya Wacana Christian University, Salatiga. The research instrument is the researcher himself as the main instrument and supporting instruments are the form of test questions and interview guides. The test method in the form of logarithmic equation questions and interview methods were used to obtain research data. Data analysis techniques used include data reduction, data analyzed by Pirie-Kieren theory, data presentation and conclusion drawing. Test the validity of the data using triangulation techniques. The results showed that subject 1 and subject 2 had reached the eighth layer, namely inventising. While subject 3 reaches the seventh layer, namely structuring. Based on research results, it can be concluded that preservice mathematis teacher have reached the eighth layer, namely inventising.
\end{abstract}

Keywords: Layer of conceptual understanding; logarithm; preservice mathematis teacher. 
DOI: https://doi.org/10.24127/ajpm.v10i3.3701

\section{PENDAHULUAN}

Pemahaman konsep merupakan bagian penting dari pengetahuan, bersamaan dengan pengetahuan faktual dan prosedural. Siswa yang hanya menghafal secara faktual dan prosedural tanpa adanya pemahaman konsep akan ragu-ragu menggunakan apa yang sudah mereka ketahui (NCTM, 2000). Sejalan dengan hal tersebut, Manda \& Putra (2012) mendefinisikan pemahaman konsep sebagai suatu pemahaman dimana pemahaman ini dibuktikan dengan siswa dapat menjelaskan dengan bahasanya sendiri materi yang diajarkan, bukan hanya sekedar menghafal. Berdasar hal tersebut, siswa yang memiliki pemahaman konsep yang baik tidak hanya menghafal pengetahuan secara faktual dan prosedural, tetapi juga dapat mengkomunikasikan pemahamannya dengan bahasa sendiri..

(Pirie \& Kieren, 1994) mendefinisikan suatu pemahaman sebagai keseluruhan proses yang dinamis, bergerak melalui level atau tingkatan namun tidak linear dan terdapat proses rekursif di dalamnya. Hampir semua teori pemahaman konsep yang berkembang menganggap pemahaman konsep sebagai suatu proses linear (Muliawati, 2020). Namun teori pemahaman Pirie \& Kieren merupakan teori yang menekankan bahwa pertumbuhan pemahaman tidak linear, tetapi sebaliknya proses pemahaman bersifat dinamis (Gülkılıka et al., 2015). Pirie \& Kieren memodelkan pemahaman matematika menjadi delapan lapisan pemahaman. Delapan lapisan tersebut antara lain primitive knowing, image making, image having, property noticing, formalizing, observing, structuring, inventising. Proses pemahaman Pirie \& Kieren diilustrasikan seperti lapisan bawang yang berlapis-lapis (Safitri et al., 2018).
Sehingga pemahaman seseorang pada lapisan kedelapan atau inventising dapat menjadi primitive knowing untuk materi baru. Pirie \& Kieren menggambarkan lapisan pemahaman seperti pada Gambar 1.

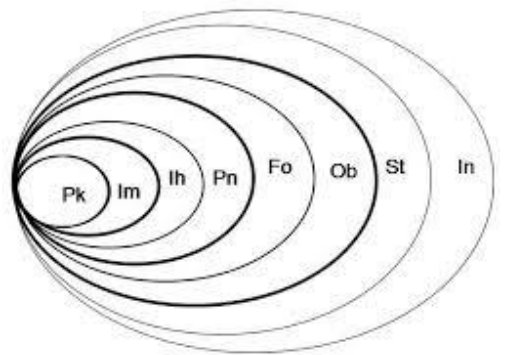

Gambar 1. Lapisan pemahaman konsep teori Pirie \& Kieren (Sagala, 2017)

Pemahaman konsep sangat diperlukan dalam matematika. NCTM (2000) menyatakan bahwa siswa harus belajar matematika dengan pemahaman. Sejalan dengan hal itu, Mawaddah \& Maryanti (2016) menegaskan bahwa dalam pembelajaran matematika, siswa harus memiliki pemahaman konsep sehingga dapat menerapkan konsep dengan efisien dan tepat. Suatu materi dengan materi lainnya dalam matematika saling berhubungan. Oleh sebab itu, siswa yang tidak memahami konsep suatu materi dalam matematika dapat menghambat penguasaan materi berikutnya (Puspitasari \& Prihatnani, 2018).

Logaritma adalah salah satu materi matematika yang membutuhkan pemahaman konsep. Pada masalah logaritma, diperlukan minimal satu sifat logaritma untuk menyelesaikan masalah. Banyaknya sifat-sifat logaritma, membuat siswa cenderung hanya menghafal sifat-sifat logaritma tanpa memahami konsep dasar logaritma. Padahal memfokuskan pemahaman konsep dasar materi logaritma, dirasa sesuai untuk mempermudah siswa mempelajari logaritma (Supardi et al., 2019). 
DOI: https://doi.org/10.24127/ajpm.v10i3.3701

Beberapa penelitian terdahulu menunjukan bahwa pemicu kesalahan siswa dalam menyelesaikan soal logaritma adalah kurangnya pemahaman konsep siswa. Hasil penelitian Hananta \& Ratu (2021) menyatakan bahwa salah satu pemicu kesalahan siswa dalam menyelesaikan soal logaritma adalah siswa masih bingung dalam menggunakan sifat-sifat logaritma karena kurang memahami konsepnya. Kemudian hasil penelitian Angraini \& Prahmana (2018) juga menunjukan bahwa siswa tidak mampu menyelesaikan masalah logaritma karena tidak memahami konsep logaritma.

Pemahaman konsep siswa dipengaruhi oleh beberapa faktor, salah satunya adalah peran guru (Damayanti \& Mayangsari, 2017). Peran guru tidak hanya sebagai validator atau yang menyatakan benar atau salah pekerjaan siswa, tetapi juga sebagai pembimbing yang menghargai setiap jawaban siswa. Menurut Mulyono \& Hapizah (2018), dalam pembelajaran matematika, guru matematika harus memberikan kesempatan siswa untuk mengungkapkan pemahaman konsepnya. Seharusnya guru matematika tidak hanya mentransfer pengetahuan saja tetapi juga menggali pemahaman konsep siswa. Oleh sebab itu, guru matematika harus memiliki pemahaman konsep yang baik agar siswanya juga memiliki pemahaman konsep yang baik.

Elemen penting dari kompetensi profesional seorang guru adalah pemahaman konsep (Sagala, 2017). Oleh sebab itu, untuk melahirkan guru matematika yang profesional, pemahaman konsep perlu ditanamkan dengan benar sejak awal. Sehingga sebagai mahasiswa calon guru matematika, penting untuk memiliki pemahaman konsep yang baik (Pramasdyahsari \& Rubowo, 2020).
Pada jenjang pendidikan tinggi, khususnya pada program studi pendidikan matematika, terdapat pula materi logaritma. Konsep logaritma digunakan pada beberapa mata kuliah di perguruan tinggi, seperti matematika dasar, kalkulus dan persamaan diferensial, sehingga konsep logaritma perlu dikuasai mahasiswa calon guru matematika. Selain itu, materi logaritma merupakan materi yang diajarkan pada jenjang pendidikan menengah. Menurut Ario (2017), mahasiswa calon guru matematika wajib menguasai semua materi yang diajarkan di sekolah dengan baik. Dengan pemahaman konsep logaritma yang baik, diharapkan pemahaman konsep yang sudah diperoleh di perguruan tinggi menjadi bekal mahasiswa ketika mengajar di sekolah.

Berdasarkan latar belakang di atas maka akan diteliti lapisan pemahaman konsep mahasiswa calon guru matematika dalam menyelesaikan soal logaritma. Menurut Sagala \& Hatip (2018), mahasiswa calon guru matematika harus memenuhi seluruh lapisan pemahaman konsep, agar menjadi guru yang profesional. Mahasiswa calon guru matematika harus mampu mencapai lapisan kedelapan (Inventising), yaitu membuat pertanyaan atau soal baru dari pemahaman yang telah didapat pada lapisan sebelumnya. Hal ini berkaitan dengan tugas guru yang harus mampu membuat soal atau pertanyaan sendiri, yang nantinya diberikan kepada siswa. Oleh sebab itu penting untuk mengetahui sejauh mana lapisan pemahaman konsep mahasiswa calon guru matematika dalam menyelesaikan soal logaritma. Penelitian ini diharapkan dapat memberi informasi sejauh mana lapisan pemahaman konsep mahasiswa calon guru matematika dalam 
DOI: https://doi.org/10.24127/ajpm.v10i3.3701

menyelesaikan soal logaritma. Hasil penelitian ini diharapkan dapat menjadi bahan evaluasi bagi mahasiswa dan juga dosen guna meningkatkan kualitas pembelajaran.

\section{METODE PENELITIAN}

Jenis penelitian ini adalah penelitian deskriptif kualitatif. Penelitian ini dilakukan pada Januari 2020 sampai April 2021 di Universitas Kristen Satya Wacana. Subjek penelitian dipilih menggunakan teknik purposive sampling dengan ketentuan mahasiswa aktif dengan IPK tertinggi yang telah memperoleh atau mempelajari materi logaritma.

Berdasar ketentuan subjek di atas, terpilih 3 mahasiswa aktif Program Studi Pendidikan Matematika, FKIP, UKSW dengan IPK tertinggi pada angkatan 2018 sebagai subjek 1 (S1), angkatan 2019 sebagai subjek 2 (S2) dan angkatan 2020 sebagai subjek 3 (S3). Instrumen penelitian ini adalah peneliti sendiri sebagai instrumen utama dan instrumen pendukung yang berupa soal tes, pedoman wawancara dan alat rekam.

Pengumpulan data penelitian dilakukan dengan menggunakan metode tes dan wawancara. Tes yaitu tes soal persamaan logaritma yang terdiri dari 3 soal essay dan wawancara yaitu wawancara semi terstruktur untuk memperoleh keterangan lebih dalam mengenai lapisan pemahaman konsep subjek.

Analisis data dimulai dari reduksi data, yaitu pemilihan data yang akan dianalisis dengan teori pemahaman Pirie-Kieren. Kemudian data disajikan berdasarkan analisis indikator pada tiap lapisan. Setelah itu, dilakukan penarikan kesimpulan dari data yang sudah diperoleh. Triangulasi teknik digunakan pada penelitian ini untuk memeriksa keabsahan data.

Berikut indikator yang digunakan untuk mengukur lapisan pemahaman konsep mahasiswa calon guru matematika dalam menyelesaikan soal logaritma. Indikator lapisan pemahaman konsep mahasiswa calon guru matematika dalam menyelesaikan soal logaritma dapat dilihat pada Tabel 1 .

Tabel 1. Indikator lapisan pemahaman konsep logaritma

\begin{tabular}{ll}
\hline \multicolumn{1}{c}{ Lapisan } & \multicolumn{1}{c}{ Indikator } \\
\hline Primitive & 1. Mahasiswa dapat menjelaskan apa yang ditanyakan pada soal. \\
knowing & $\begin{array}{l}\text { 2. Mahasiswa dapat menjelaskan komponen pada soal yang harus } \\
\text { diperhatikan sebagai penentu penyelesaian sesuai dengan istilah dalam }\end{array}$ \\
& logaritma. \\
& 3. Mahasiswa dapat menjelaskan syarat penyelesaian persamaan logaritma \\
& bentuk $f(x) \log g(x)=c$ dengan mengaitkan definisi logaritma. \\
Image & Mahasiswa dapat mengaitkan soal dengan bentuk umum persamaan \\
making & logaritma $f(x) \log g(x)=c$. \\
Image & $\begin{array}{l}\text { 1. Mahasiswa dapat menjelaskan gambaran langkah penyelesaian yang } \\
\text { dilakukan. }\end{array}$ \\
Paving & 2. Mahasiswa dapat menjelaskan tujuan langkah yang dilakukan. \\
noticing & 1. Mahasiswa dapat menyebutkan konsep atau materi apa saja yang \\
& digunakan dalam menyelesaikan masalah. \\
& 2. Mahasiswa dapat menggunakan sifat logaritma untuk menyelesaikan \\
masalah.
\end{tabular}


DOI: https://doi.org/10.24127/ajpm.v10i3.3701

\begin{tabular}{|c|c|}
\hline Lapisan & Indikator \\
\hline & $\begin{array}{l}\text { 3. Mahasiswa dapat menggunakan konsep bentuk pangkat untuk } \\
\text { menyelesaikan masalah. }\end{array}$ \\
\hline & $\begin{array}{l}\text { 4. Mahasiswa dapat menggunakan syarat persamaan logaritma dalam } \\
\text { menyelesaikan masalah. }\end{array}$ \\
\hline Formalizing & $\begin{array}{l}\text { Mahasiswa dapat menemukan pola langkah pengerjaan soal persamaan } \\
\text { logaritma dengan bentuk umum }{ }^{f(x)} \log g(x)=c \text {. }\end{array}$ \\
\hline Obser & $\begin{array}{l}\text { Mahasiswa dapat menggunakan pola langkah pengerjaan soal persamaan } \\
\text { logaritma dengan bentuk umum }{ }^{f(x)} \log g(x)=c \text { pada masalah serupa. }\end{array}$ \\
\hline \multirow[t]{2}{*}{ Structuring } & $\begin{array}{l}\text { 1. Mahasiswa dapat menjelaskan teorema yang menggabungkan konsep } \\
\text { logaritma dan bentuk pangkat dengan alasan yang logis. }\end{array}$ \\
\hline & $\begin{array}{l}\text { 2. Mahasiswa dapat menjelaskan hasil penyelesaian soal dengan alasan yang } \\
\text { logis. }\end{array}$ \\
\hline Inventising & $\begin{array}{l}\text { Mahasiswa dapat membuat soal persamaan logaritma baru berdasarkan } \\
\text { pemahaman saat mengerjakan soal sebelumnya. }\end{array}$ \\
\hline
\end{tabular}

\section{HASIL DAN PEMBAHASAN}

Berdasar analisis hasil tes dan wawancara ketiga subjek, diperoleh hasil dan pembahasan. Berikut hasil penelitian dan pembahasan lapisan pemahaman konsep mahasiswa calon guru matematika dalam menyelesaikan soal logaritma.

\section{1) Lapisan Primitive Knowing}

Ketika wawancara, S1, S2 dan S3 mengatakan bahwa yang dicari dari soal adalah himpunan penyelesaian. Kemudian ketiga subjek juga mengatakan bahwa yang dimaksud himpunan penyelesaian adalah mencari nilai $x$ yang memenuhi persamaan. Hal ini menunjukan bahwa ketiga subjek dapat menjelaskan apa yang ditanyakan pada soal persamaan logaritma. Sejalan dengan Safitri et al. (2018) yang menyatakan bahwa subjek mencapai lapisan primitive knowing karena dapat menyebutkan apa yang ditanyakan pada soal. Selanjutnya, ketika wawancara ketiga subjek dapat menyebutkan bagian mana pada soal yang merupakan basis, numerus dan hasil logaritma dengan tepat. Hal ini menunjukan bahwa ketiga subjek dapat menjelaskan komponen-komponen pada soal yang harus diperhatikan sebagai penentu penyelesaian sesuai dengan istilahistilah dalam logaritma. Suindayati et al. (2019) menyatakan bahwa subjek dapat mencapai lapisan primitive knowing karena mampu menyebutkan dan menjelaskan definisi dari istilah-istilah pada soal. Selain itu, ketiga subjek dapat menjelaskan syarat penyelesaian persamaan logaritma bentuk ${ }^{f(x)} \log g(x)=c$ yang digunakan untuk menyelesaikan soal. Ketika wawancara, ketiga subjek mengatakan bahwa dalam soal persamaan logaritma terdapat syarat basis $>0$, basis $\neq 1$ dan numerus $>0$. Bahkan S2 dan S3 dapat mengaitkan syarat basis dan numerus dengan definisi logaritma. Sagala (2016) menjelaskan bahwa subjek memenuhi lapisan primitive knowing karena mampu memahami konsep yang diperlukan dalam menyelesaikan masalah.

Berdasar penjelasan di atas, S1, S2 dan S3 telah mampu memenuhi ketiga indikator pada lapisan primitive knowing. Oleh sebab itu, dapat dikatakan bahwa mahasiswa calon guru matematika telah mencapai lapisan primitive knowing. 
DOI: https://doi.org/10.24127/ajpm.v10i3.3701

\section{2) Lapisan Image Making}

Pada lapisan ini, S1, S2 dan S3 dapat mengaitkan soal dengan bentuk umum persamaan logaritma ${ }^{f(x)} \log g(x)=c$. Ketika wawancara, ketiga subjek menyebutkan bentuk umum dari soal persamaan logaritma yang diberikan dengan tepat berdasarkan pemahaman yang sudah diperoleh pada lapisan primitive knowing, yaitu basis dan numerus logaritma berupa fungsi. Lapisan image making mendorong subjek untuk menggunakan pengetahuan sebelumnya untuk mengetahui pemahaman baru (Putri, 2019). Habibie \& Turmudi (2021) juga menyatakan bahwa lapisan image making berupa kemampuan subjek dalam menggunakan pengetahuan sebelumnya.

Berdasar penjelasan di atas, S1, S2 dan S3 telah mampu memenuhi indikator pada lapisan image making. Oleh sebab itu, dapat dikatakan bahwa mahasiswa calon guru matematika telah mencapai lapisan image making.

\section{3) Lapisan Image Having}

Ketika wawancara, S1, S2 dan S3 menyebutkan gambaran langkah penyelesaian yang dilakukan dengan runtut dan tepat. Selain itu, ketiganya juga menyebutkan tujuan langkah penyelesaian yang digunakan dalam. Hal ini menunjukan bahwa ketiga subjek dapat menjelaskan gambaran langkah penye-lesaian yang akan dilakukan dan dapat menjelaskan tujuan langkah-langkah tersebut dilakukan. Muliawati (2020) menjelaskan bahwa pada lapisan image having, subjek menjelaskan cara yang digunakan dalam penyelesaian soal secara lengkap. Hakim (2019) juga menjelaskan bahwa subjek menjelaskan ide yang telah ditulis dengan baik menunjukan subjek mencapai lapisan image having.
Berdasar penjelasan di atas, S1, S2, dan S3 telah mampu memenuhi indikator pada lapisan image having. Oleh sebab itu, dapat dikatakan bahwa mahasiswa calon guru matematika telah mencapai lapisan image having.

\section{4) Lapisan Property Noticing}

Ketercapaian ketiga subjek pada lapisan ini dianalisis berdasarkan hasil pengerjaan soal tes ketiga subjek. Jawaban tertulis soal tes $\mathrm{S} 1$ dapat dilihat pada Gambar 2, jawaban tertulis S2 pada Gambar 3, dan jawaban tertulis S3 pada Gambar 4.
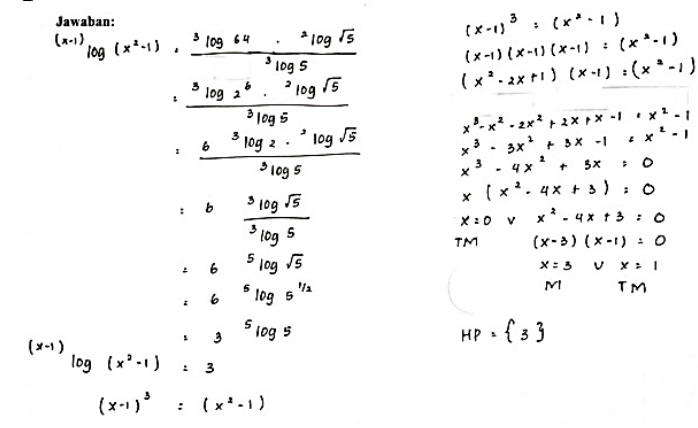

Gambar 2. Jawaban tertulis soal tes S1

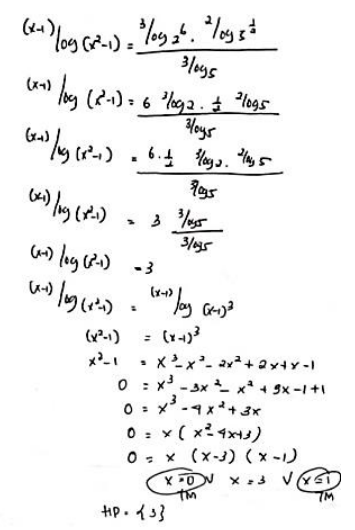

Gambar 3. Jawaban tertulis soal tes S2

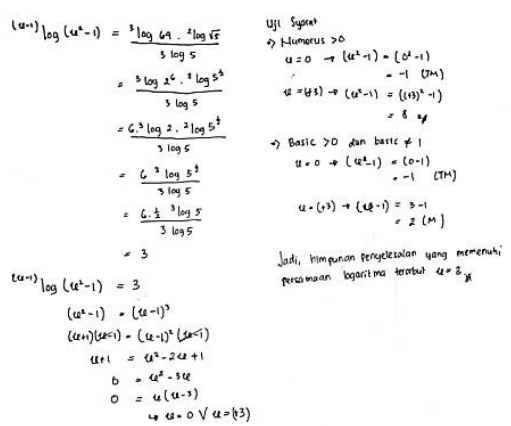

Gambar 4. Jawaban tertulis soal tes S3 
DOI: https://doi.org/10.24127/ajpm.v10i3.3701

Berdasarkan hasil jawaban tertulis soal tes dari ketiga subjek pada Gambar 2, Gambar 3 dan Gambar 4, ketiga subjek dapat menggunakan sifatsifat logaritma, konsep bentuk pangkat (eksponen) dan syarat persamaan logaritma dalam menyelesaikan masalah dengan tepat. Setyawati \& Ratu (2019) menyatakan bahwa pada lapisan property noticing subjek menghubungkan gambaran abstrak dengan konsep atau sifat-sifat. Ketika wawancara, ketiga subjek menyebutkan sifat-sifat dan syarat logaritma yang digunakan dalam menyelesaikan masa-lah. Selain itu, S1, S2 dan S3 tidak hanya memakai konsep logaritma saja dalam menyelesaikan soal, tetapi juga memakai konsep lainnya dalam matematika. Ketika wawancara, ketiga subjek menyebutkan konsep atau materi apa saja yang dipakai dalam menyele-saikan soal tes. Pada lapisan property noticing, subjek menggabungkan dan menghubungkan beberapa teorema/ konsep (Cahyatia \& Kriswandani, 2017).

Berdasarkan penjelasan di atas, S1, S2 dan S3 telah mampu memenuhi keempat indikator pada lapisan property noticing. Oleh sebab itu, dapat dikatakan bahwa mahasiswa calon guru matematika telah mencapai lapisan property noticing.

\section{5) Lapisan Formalizing}

Ketika wawancara, S1, S2 dan S3 menjelaskan dengan tepat pola langkah penyelesaian yang akan dilakukan jika menemukan soal persamaan logaritma bentuk umum ${ }^{f(x)} \log g(x)=c$. Hal ini menunjukan bahwa ketiga subjek telah menemukan pola langkah pengerjaan soal persamaan logaritma dengan bentuk umum ${ }^{(x)} \log g(x)=c$ berdasarkan pemahaman masingmasing subjek setelah menyelesaikan soal tes awal. Sejalan dengan hal tersebut, Pratama (2017) menjelaskan bahwa subjek mencapai lapisan formalizing karena telah memperoleh pengetahuan baru berdasarkan pemahaman atas aturan-aturan, sifat maupun cara yang digunakan dalam menyelesaikan soal. Muliawati (2020) juga menyatakan bahwa pada lapisan formalizing subjek mampu menemukan sendiri konsep untuk menyelesaikan masalah.

Berdasar penjelasan di atas, S1, S2 dan S3 telah mampu memenuhi indikator pada lapisan formalizing. Oleh sebab itu, dapat dikatakan bahwa mahasiswa calon guru matematika telah mencapai lapisan formalizing.

\section{6) Lapisan Observing}

Pada lapisan ini, ketiga subjek diberikan 2 soal yang serupa dengan tes awal. Jawaban tertulis S1 dapat dilihat pada Gambar 5 dan 6, jawaban tertulis S2 pada Gambar 7 dan 8, serta jawaban tertulis S3 pada Gambar 9 dan 10.

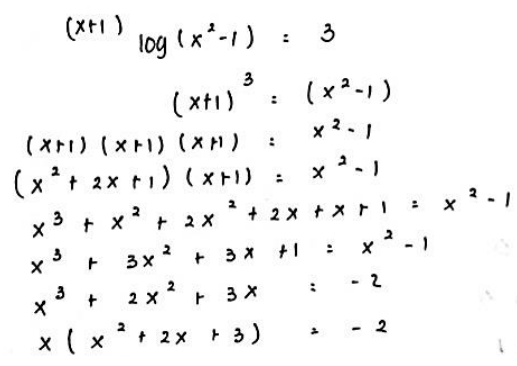

Gambar 5. Jawaban tertulis S1 pada soal observing 1

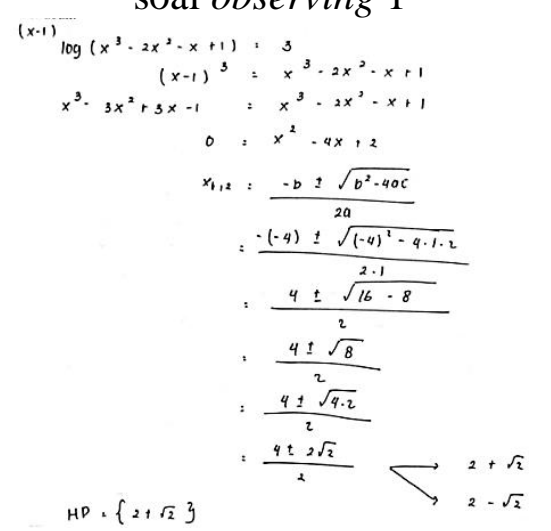

Gambar 6. Jawaban tertulis S1 pada soal observing 2 
DOI: https://doi.org/10.24127/ajpm.v10i3.3701

Gambar 5 dan Gambar 6 menunjukan bahwa S1 hanya mampu memperoleh penyelesaian dari satu soal saja, yaitu soal observing 2. Ketika wawancara S1 mengatakan bahwa merasa kesulitan untuk memperoleh penyelesaian soal observing 1 karena lupa cara pemfaktoran polinomial. Meskipun demikian, S1 telah menggunakan pola langkah pengerjaan yang sudah didapat dari lapisan sebelumnya.

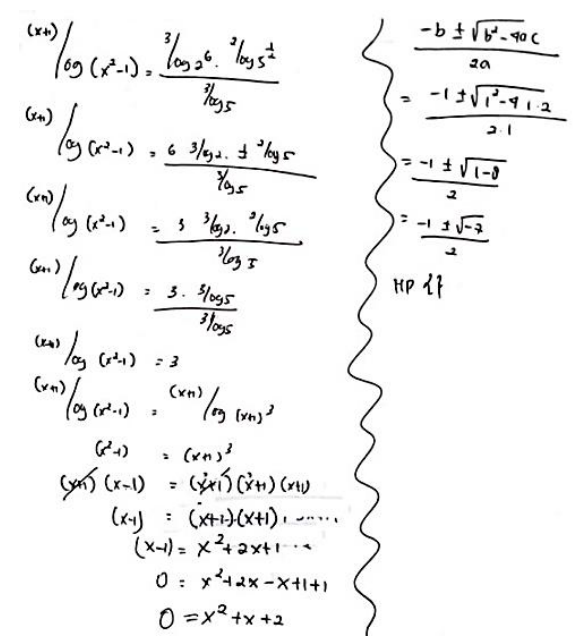

Gambar 7. Jawaban Tertulis S2 pada Soal Observing 1

$$
\begin{aligned}
& (x+1) / y\left(x^{3}-2 x^{2}-x+1\right)=3 \\
& (x+1) / \log \left(x^{3}-2 x^{2}-x+1\right)=(x-1) / \log (x+1)^{3} \\
& x^{3}-2 x^{2}-x+1=(x-1)^{3} \\
& x^{3}-2 x^{2}-x+1=x^{3}-3 x^{2}+3 x-1 \\
& 0=x^{3}-x^{3}-3 x^{2}+2 x^{2}+3 x+x-1-1 \\
& 0=-x^{2}+4 x-2 \\
& 0=x^{2}-4 x+2 \\
& \begin{aligned}
\frac{-b \pm \sqrt{b^{2}-4 a c}}{2 a} & =\frac{-(-4) \pm \sqrt{(-)^{2}-4(1) \cdot 2}}{2(1)} \\
& =\frac{4 \pm \sqrt{16-1}}{2} \\
& =\frac{4 \pm \sqrt{7}}{2}
\end{aligned} \\
& \frac{4+\sqrt{3}}{2} \vee \frac{9-\sqrt{3}}{2} \\
& x=\frac{9+2 \sqrt{2}}{2} \sqrt{ } \frac{9-2 \sqrt{2}}{2} \\
& \text { 4p. \{xom }
\end{aligned}
$$

Gambar 8. Jawaban Tertulis S2 pada Soal Observing 2
Gambar 7 dan Gambar 8 menunjukan bahwa S2 mampu menyelesaikan dua soal dengan tepat. Selain itu, S2 juga telah menggunakan pola langkah pengerjaan yang sudah didapat dari lapisan sebelumnya.

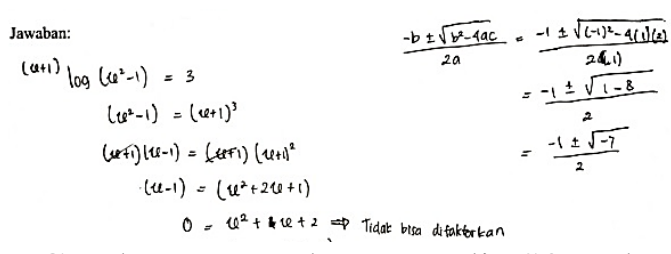

Gambar 9. Jawaban Tertulis S3 pada Soal Observing 1

$$
\begin{aligned}
& \left(u^{3}-2 u^{2}-u+1\right)=(u-1)^{3} \\
& \left(u^{3}-2 u^{2}-u+1\right)=(u-1)(u-1)^{2} \\
& \left(u^{3}-2 u^{2}-u+1\right)=(u-1)\left(u^{2}-2 u+1\right) \\
& \left(u^{3}-2 u^{2}-u+1\right)=\left(u^{3}-2 u^{2}+u-u^{2}+2 u-1\right. \\
& u^{3}-2 u^{2}-u+1=u^{5}-3 u^{2}+3 u-1 \\
& u^{2}-4 u+2=0 \\
& \frac{-b \pm \sqrt{b^{2}-4 a c}}{2 a}=\frac{-(-a) \pm \sqrt{(-a)^{2}-4(1)(2)}}{2(1)} \\
& =\frac{4 \pm \sqrt{18-8}}{2} \\
& =\frac{4 \pm \sqrt{8}}{2} \\
& =\frac{4 \pm 2 \sqrt{2}}{2} \\
& =2 \pm \sqrt{2}<\begin{array}{l}
u_{1}=2+\sqrt{2} \\
u_{2}=2-\sqrt{2}
\end{array}
\end{aligned}
$$

Gambar 10. Jawaban Tertulis S3 pada Soal Observing 2

Gambar 9 dan Gambar 10 menunjukan bahwa S3 mampu menyelesaikan kedua soal pada lapisan ini, tetapi tidak menuliskan himpunan penyelesaian dari kedua soal. Namun ketika wawancara, S3 mengatakan bahwa penyelesaian soal observing 1 adalah tidak ada, sedangkan penyelesaian soal observing 2 adalah $2+\sqrt{2}$. Hal ini menunjukan bahwa S3 telah mampu memperoleh penyelesaian dari kedua soal yang diberikan dan telah menggunakan pola langkah pengerjaan yang sudah didapat dari lapisan sebelumnya. 
DOI: https://doi.org/10.24127/ajpm.v10i3.3701

Berdasarkan pembahasan dari jawaban tertulis ketiga subjek, ketiga subjek telah menggunakan pola langkah pengerjaan soal persamaan logaritma dengan bentuk umum ${ }^{f(x)} \log g(x)=c$ pada masalah serupa. Ketiga subjek menggunakan pola langkah pengerjaan yang sudah diperoleh dari lapisan formalizing untuk menyelesaikan 2 soal yang diberikan pada lapisan ini. Sependapat dengan hal tersebut, Asih et al. (2020) menjelaskan bahwa pada lapisan observing subjek mampu mengkoordinasikan aktivitas formal pada lapisan formalizing guna menyelesaikan masalah yang dihadapi. Setyawati \& Ratu (2019) juga menjelaskan bahwa pada lapisan observing subjek mengaplikasikan konsep atau sifat yang diperoleh pada lapisan formalizing.

Berdasarkan penjelasan di atas, S1, S2 dan S3 telah mampu memenuhi indikator pada lapisan observing. Oleh sebab itu, dapat dikatakan bahwa mahasiswa calon guru matematika telah mencapai lapisan observing.

\section{7) Lapisan Structuring}

Berdasarkan jawaban tertulis soal tes pada Gambar 2 dan Gambar 4, S1 dan S3 menggunakan teorema definisi logaritma yang menggabungkan konsep logaritma dan bentuk pangkat dalam menyelesaikan soal tes. Sedangkan pada Gambar 3, S2 tidak menggunakan teorema definisi logaritma. Namun ketika wawancara, ketiga subjek menyebutkan dan menjelaskan bagianbagian langkah penyelesaian yang menggabungkan konsep logaritma dan bentuk pangkat (eksponen). Hal ini menunjukan bahwa ketiga subjek telah mampu memenuhi indikator lapisan structuring karena mampu menggunakan dan menjelaskan langkah penyelesaian yang menggabungkan konsep logaritma dan bentuk pangkat. Selain itu, ketika wawancara ketiga subjek mengatakan bahwa alasan hasil penyelesaian soal observing 1 tidak ada (himpunan kosong) karena saat melakukan pemfaktoran dengan rumus abc diperoleh nilai $\sqrt{-7}$. Sedangkan untuk soal observing 2, penyelesaiannya hanya $2+\sqrt{2}$, karena $2+\sqrt{2}$ yang memenuhi syarat basis dan numerus dalam persamaan logaritma. Hal ini menunjukan bahwa ketiga subjek juga dapat menjelaskan hasil penyelesaian soal pada lapisan observing dengan alasan yang logis. Pada lapisan structuring subjek mampu menghubungkan beberapa teorema dan membuktikan dengan argumen yang logis (Asih et al., 2020; Suindayati et al., 2019; Syafri \& Isran, 2016).

Berdasarkan penjelasan di atas, S1, S2 dan S3 telah mampu memenuhi indikator pada lapisan structuring. Oleh sebab itu, dapat dikatakan bahwa mahasiswa calon guru matematika telah mencapai lapisan structuring.

\section{8) Lapisan Inventising}

Pada lapisan ini, ketiga subjek diminta untuk membuat soal baru yang serupa dengan soal observing 1 dengan syarat hanya boleh mengubah bagian numerus saja dan hasil penyelesaiannya harus bilangan real. Jawaban tertulis ketiga subjek dapat dilihat pada Gambar 11, Gambar 12 dan Gambar 13.

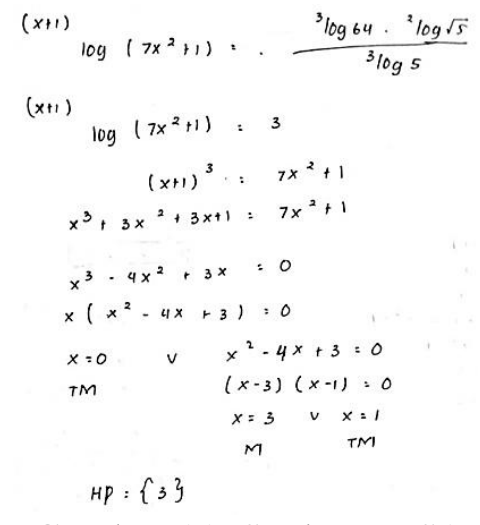

Gambar 11. Soal Baru S1 
DOI: https://doi.org/10.24127/ajpm.v10i3.3701

$$
\begin{aligned}
& (x+1) \log _{\left(2 x^{3}+2 x^{2}-2 x-2\right)}=\frac{3 / \log 64 \cdot{ }^{2} \log r r}{2 \log r} \\
& (x+1) \log _{\left(2 x^{3}+2 x^{2}-2 x-2\right)}=3 \\
& (x+1) \log _{\left(2 x^{3}+2 x^{2}-2 x-2\right)\left(2 / \lg (x+1)^{3}\right.} \\
& \left(2 x^{3}+2 x^{2}-2 x-2\right)=(x+1)^{3} \\
& (x+1)(y+1)(2 x-2)=(x+1)(x+1)(x+1) \\
& (2 x-2)=(x+1) \\
& 2 x-2=x+1 \\
& 2 x-x-2-1=0 \\
& x-3=0 \\
& x=3
\end{aligned}
$$

$H_{P}=\{3\}$

Gambar 12. Soal Baru S2

$$
\begin{aligned}
& \left(u^{2}+2 u+1\right)=(u+1)^{2}(u+1) \quad(u- \\
& \begin{array}{rlrl}
(u-2)(u+1) & \left(u^{2}+2 u+1\right) & =\left(u^{2}+2 u+1\right)(u+1) \\
u^{2}-1 u^{-2} & 0 & =u+1
\end{array} \\
& \begin{array}{c}
u^{2}-1(u-2 \\
(u+1)(u+3) \quad u=-1
\end{array} \\
& \begin{array}{ll}
(u+1)(u+1) & u^{2}+a u+3 \\
\left.u^{2}+2 u+1\right) & \log \left(-u^{2}-u-2\right)=3
\end{array} \\
& u+3=u^{2}+2 u+1 \quad\left(u^{2}-u-2\right)=(u+1)^{3} \\
& =u^{2}+u-2 \quad(u+1)(u-2)=(u+1)(u+1)^{2} \\
& (u+2)(u-1) \quad u-2)=u^{2}+2 u+1 \text {. } \\
& 0=u^{2}+u+3
\end{aligned}
$$

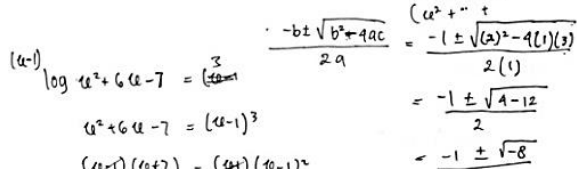

$$
\begin{aligned}
& (u+7)=u^{2}-2 u+1 \\
& 0=u^{2} \text {. }
\end{aligned}
$$

\section{Gambar 13. Oret-oretan S3}

Gambar 11 dan Gambar 12 menunjukan bahwa S1 dan S2 telah mampu membuat soal persamaan logaritma baru sesuai dengan kriteria yang diminta peneliti. Namun S2 melakukan kesalahan di bagian lingkaran merah pada Gambar 12. Seharusnya basisnya $(x+1)$, namun S2 menuliskan basisnya 3 . Tetapi jika dilihat dari langkah selanjutnya, kesalahan tersebut tidak mempengaruhi hasil akhirnya. Jadi dapat dikatakan bahwa S1 dan S2 telah mampu mencapai lapisan inventising karena dapat membuat soal persamaan logaritma baru. Sagala (2017) menjelaskan bahwa mahasiswa calon guru matematika memenuhi salah satu indikator lapisan inventising yaitu membuat pertanyaan baru dalam bentuk soal. Sedangkan pada Gambar 13, menunjukan S3 sudah berusaha mencari soal baru yang sesuai dengan kriteria yang diminta, namun tidak mampu menemukan soal baru yang sesuai kriteria.

Ketika wawancara, S1 mengatakan bahwa alasan mengganti numerus soal dengan $\left(7 x^{2}+1\right)$ agar bentuknya kembali ke soal tes awal dan hasil penyelesaiannya bilangan real. Hal ini menunjukan bahwa $\mathrm{S} 1$ dapat membuat soal persamaan logaritma baru berdasarkan pemahaman yang diperoleh pada pengerjaan soal sebelumnya. S2 mengatakan telah mengganti numerus soal dengan $\left(2 x^{3}+2 x^{2}-2 x-2\right)$, karena dengan begitu, kedua ruas memiliki faktor $(x+1)^{2}$ yang dapat disederhanakan. Safitri et al. (2018) menyatakan bahwa subjek mencapai lapisan inventising apabila subjek membuat pertanyaan baru yang berhubungan dengan soal yang sudah diberikan. Sedangkan S3, ketika wawancara, mengatakan bahwa merasa kesulitan dalam membuat soal baru dengan kriteria yang sudah ditentukan. Berikut hasil wawancara dengan S3.

$$
\begin{array}{ll}
\text { P38102 : Oke gimana? } & \text { S38102 : Susah, gak ketemu hehe } \\
\text { P38103 } & \text { Gak ketemu ya? Berarti } \\
& \text { belum bisa buat soal baru } \\
& \text { ya? }
\end{array}
$$

Berdasarkan penjelasan di atas, $\mathrm{S} 1$ dan S2 telah mampu memenuhi 
indikator pada lapisan inventising, sedangkan S3 tidak mampu memenuhi indikator lapisan inventising.

Pembahasan hasil penelitian di atas menunjukan bahwa S1 dan S2 telah memenuhi kedelapan lapisan, yaitu primitive knowing, image making, image having, property noticing, formalizing, observing, structuring, inventising. Namun S3 hanya mampu memenuhi ketujuh lapisan, yaitu primitive knowing, image making, image having, property noticing, formalizing, observing, structuring. Meskipun S3 tidak mencapai lapisan inventising, dapat dikatakan bahwa mahasiswa calon guru matematika telah mencapai lapisan kedelapan, yaitu lapisan inventising karena S1 dan S2 telah memenuhi indikator lapisan inventising. Hasil penelitian ini diharapkan dapat menjadi bahan evaluasi bagi mahasiswa untuk lebih meningkatkan pemahaman konsepnya terhadap materi logaritma, dan juga dapat menjadi bahan evaluasi bagi dosen untuk meningkatkan kualitas pembelajaran yang diberikan kepada mahasiswa khususnya pada mata kuliah yang menggunakan konsep logaritma.

\section{KESIMPULAN DAN SARAN}

Berdasar dari hasil penelitian dan pembahasan, dapat disimpulkan bahwa mahasiswa calon guru matematika telah mencapai lapisan kedelapan teori pemahaman Pirie-Kieren, yaitu inventising.

Adapun saran yang diberikan adalah diharapkan penelitian selanjutnya dapat memilih materi lain yang lebih menarik untuk diteliti dan memilih kriteria subjek yang lebih variatif agar hasil penelitian setiap subjek lebih bervariasi. Selain itu, diharapkan penelitian ini dijadikan acuan untuk penelitian-penelitian selanjutnya.

\section{DAFTAR PUSTAKA}

Angraini, P., \& Prahmana, R. C. I. (2018). Analisis Kemampuan Pemahaman Matematis Pada Materi Bentuk Pangkat, Akar, dan Logaritma di SMK. Journal of Honai Math, 1(1), 1. https://doi.org/10.30862/jhm.v1i1. 716

Ario, M. (2017). Profil Penguasaan Materi Matematika Sekolah Mahasiswa Pendidikan Matematika Semester VI. AKSIOMA: Jurnal Program Studi Pendidikan Matematika, 6(3), 385. https://doi.org/10.24127/ajpm.v6i 3.1129

Asih, Rohman, N., \& Utami, A. D. (2020). Profil Lapisan Pemahaman Konsep Barisan dan Deret Berdasar Teori Pirie Kieren. Jurnal Pendidikan Edutama.

Cahyatia, A. M. D., \& Kriswandani. (2017). Lapisan Pemahaman Konsep Matematika Dalam Menyelesaikan Soal TIMSS Bagi Siswa SMP Kelas VIII. Jurnal Inovasi Pendidikan Dan Pembelajaran Matematika, 3(2), 83-97.

Damayanti, N. W., \& Mayangsari, S. N. (2017). Analisis Kesalahan Siswa Dalam Pemahaman Konsep Operasi Hitung Pada Pecahan. Edutic - Scientific Journal of Informatics Education, 4(1), 1-7. https://doi.org/10.21107/edutic.v4 i1.3389

Gülkılıka, H., Uğurlub, H. H., \& Yürükc, N. (2015). Examining Students' Mathematical Understanding of Geometric Transformations Using the PirieKieren Model. Kuram ve Uygulamada Egitim Bilimleri, 15(6), 1531-1548. 
DOI: https://doi.org/10.24127/ajpm.v10i3.3701

https://doi.org/10.12738/estp.2015 .6 .0056

Habibie, R. K., \& Turmudi, T. (2021). Assesment for Learning Dalam Model Pemahaman Pirie \& Kieren. Jurnal Cakrawala Pendas, 7(1), 18-26. https://doi.org/10.31949/jcp.v7i1. 2237

Hakim, F. (2019). Analisis Pemahaman Mahasiswa PPS UNM Berpandu Teori Pirie-Kieren Dalam Menyelesaikan Masalah Pembuktian Pada Teori Grup Ditinjau dari Gaya Kognitif dan Adversity Quotient. Journal on Pedagogical Mathematics, 1(2), 86-101.

Hananta, F. I., \& Ratu, N. (2021). Analisis Kesalahan Siswa dalam Menyelesaikan Soal Logaritma. Jurnal Cendekia: Jurnal Pendidikan Matematika, 5(1), 542-550.

https://doi.org/10.31004/cendekia. v5i1.507

Manda, T. G., \& Putra, A. A. (2012). Pemahaman Konsep Luas dan Volume Bangun Ruang Sisi Datar Siswa Melalui Penggunaan Model Learning Cycle 5E Disertai Peta Konsep. Jurnal Pendidikan Matematika, 1(1), 27-32.

Mawaddah, S., \& Maryanti, R. (2016). Kemampuan Pemahaman Konsep Matematis Siswa SMP dalam Pembelajaran Menggunakan Model Penemuan Terbimbing (Discovery Learning). EDU-MAT: Jurnal Pendidikan Matematika, 4(1), 76-85. https://doi.org/10.20527/edumat.v $4 \mathrm{i} 1.2292$

Muliawati, N. (2020). Lapisan Pemahaman Mahasiswa Calon Guru Matematika Dengan Tipe Middle Ability Dalam

Menyelesaikan Soal Pembuktian Grup Berdasarkan Teori PirieKieren. JEMS: Jurnal Edukasi Matematika Dan Sains, 8(2), 157164.

Mulyono, B., \& Hapizah, H. (2018). Pemahaman Konsep Dalam Pembelajaran Matematika. KALAMATIKA Jurnal Pendidikan Matematika, 3(2), 103-122. https://doi.org/10.22236/kalamati ka.vol3no2.2018pp103-122

NCTM. (2000). Principles and Standards for School Mathematics (Vol. 148).

Pirie, S., \& Kieren, T. (1994). Growth in Mathematical Understanding: How Can We Characterise It and How Can We Represent It? Educational Studies in Mathematics, 26(2-3), 165-190. https://doi.org/10.1007/BF012736 62

Pramasdyahsari, A. S., \& Rubowo, M. R. (2020). Pemahaman Konsep Grup Mahasiswa Calon Guru Matematika dengan Kemampuan Matematika Tinggi. Prismatika: Jurnal Pendidikan Dan Riset Matematika, 2(2), 71-84. https://doi.org/10.33503/prismatik a.v2i2.681

Pratama, N. A. E. (2017). Perkembangan Pemahaman Matematis Siswa Sekolah Dasar Kelas V Berdasarkan Teori PirieKieren Pada Topik Pecahan. Sekolah Dasar: Kajian Teori Dan Praktik Pendidikan, 26(1), 77-88. https://doi.org/10.17977/um009v2 6i12017p077

Puspitasari, A. P., \& Prihatnani, E. (2018). Deskripsi Pemahaman Konsep Kejadian Majemuk Siswa Kelas XI IPA SMA Negeri 3 Salatiga. Jurnal Mitra Pendidikan (JMP Online), 2(1), 117-133. 
DOI: https://doi.org/10.24127/ajpm.v10i3.3701

Putri, R. A. (2019). Pengembangan Lembar Kegiatan Siswa (LKS) Berbasis Teori Pertumbuhan Pemahaman Matematis Pirie Kieren pada Materi Fungsi Linier Kelas X SMA/MA [Universitas Negeri Malang]. http://repository.um.ac.id/16176/

Safitri, R. I., Mulyani, S., \& Ratu, N. (2018). Profil Lapisan Pemahaman Konsep Siswa SMP Terkait Garis Tinggi Segitiga. Jurnal Ilmiah Soulmath: Jurnal Edukasi Pendidikan Matematika, 6(2), 65. https://doi.org/10.25139/smj.v6i2. 1141

Sagala, V. (2016). Profil Lapisan Pemahaman Konsep Turunan Fungsi dan Bentuk Folding Back Mahasiswa Calon Guru Berkemampuan Matematika Tinggi Berdasarkan Gender. MUST: Journal of Mathematics Education, Science and Technology, 1(2), 183. https://doi.org/10.30651/must.vli 2.237

Sagala, V. (2017). Struktur Lapisan Pemahaman Konsep Turunan Fungsi Mahasiswa Calon Guru Matematika. Jurnal Didaktik Matematika, 4(2), 125-135. https://doi.org/10.24815/jdm.v4i2. 8384

Sagala, V., \& Hatip, A. (2018). Peningkatan Lapisan Pemahaman Konsep Luas Bangun Datar Mahasiswa melalui Model Pembelajaran PRAKTAK. Jurnal Didaktik Matematika, 5(2), 3039.

https://doi.org/10.24815/jdm.v5i2. 11898

Setyawati, R. D., \& Ratu, N. (2019). Lapisan Pemahaman Konsep Matematika Dalam Soal PISA
Pada Siswa SMA. AKSIOMA: Jurnal Program Studi Pendidikan Matematika, 8(1), 193-204. https://doi.org/10.24127/ajpm.v8i 1.1890

Suindayati, S., Nur Afifah, D. S., \& Sukwatus Suja'i, I. (2019). Teori Pirie-Kieren: Lapisan Pemahaman Siswa SMP Berkemampuan Matematika Tinggi Dalam Menyelesaikan Soal Bangun Ruang. MaPan: Jurnal Matematika Dan Pembelajaran, 7(2), 211-228. https://doi.org/10.24252/mapan.20 $19 \mathrm{v} 7 \mathrm{n} 2 \mathrm{a} 4$

Supardi, A. A., Gusmania, Y., \& Amelia, F. (2019). Pengembangan Modul Pembelajaran Matematika Berbasis Pendekatan Konstruktivisme Pada Materi Logaritma. AKSIOMA : Jurnal Matematika Dan Pendidikan Matematika, 10(1), 80-92. https://doi.org/10.26877/aks.v10i1 .3744

Syafri, F. S., \& Isran, D. (2016). Pembelajaran Matematika dengan Model Teori Pirie dan Kieren. Edudikara, 1(1), 42-50 (ISSN 2541-0261). 